\title{
Lease Financing as a Performance Driver: Evidence from Oil and Gas Sector of Pakistan
}

\author{
Muhammad Usman Arshad ${ }^{* 1}$, Zahid Bashir ${ }^{2}$, Muhammad Asif ${ }^{3} \&$ Ghalib Hussain $^{4}$ \\ 1,2,3 Department of Commerce, University of Gujrat, Pakistan \\ ${ }^{4}$ University of Sargodha, Bakahar Campus, Pakistan
}

\begin{abstract}
The sole aim of the study is to analyze the effect of the lease as a potential driver of firm's financial performance in oil and gas industry of Pakistan. The population for the current research study comprises of 18 listed companies of oil and gas sector of Pakistan but the final sample includes only nine companies which were using lease financing. The data were collected from the annual reports of companies from the year 2013 to 2017. Lease financing is used as an independent variable while firm performance as dependent variable defined by ROA. ordinary least square method was used. The study concludes that financing through the lease is not a significant driver of financial performance in oil and gas companies of Pakistan and also negatively affecting it rather these companies heavily rely on debt financing which decreases their performance. Only the firm size has a positive and significant effect on a firm's performance in this sector. The policy makers and management should consider lease financing as a potential factor of decreasing the firm performance in oil and gas industry of Pakistan for future consideration. The research study has considerable importance for the oil and gas sector of Pakistan as the first in this domain for the future research, especially for the lease financing.
\end{abstract}

Key words: Lease Financing, Firm Performance, Oil, and Gas Sector of Pakistan

\section{Introduction}

\subsection{Background of the Study}

There is an alternative method of financing business assets (Salam, 2013). There are two parties involved in which one party is lessor and another party is a lessee. A lessee has the right to use the assets of the other party in the exchange of specific payment; its assets will also be available for purchase. In the Council of Islamic Ideals, the concept of taking formal rituals was presented to look at the history of leasing on 1980: In particular, in 1985, Islamic financial services were introduced from falling under the financial system. For this purpose, Government issued two notifications effective January 1, 1985 (Hameed et al., 2014) namely "banking and financial services ordinance, 1984" and "Banking companies Tribunal Ordinance, 1984" under

*Corresponding author.

Email: usman.arshad@uog.edu.pk 
which financial institutions will provide financial services. As mentioned earlier, usage of lease was initiated in 1985 in Pakistan's Islamic financial system economy. The financing of the Islamic financing lease model has also become a popular alternative source of funding. As a result of tax concessions, effective approval process, cash flow benefits and other characteristics, leasing financing has become the main source of financing. The leasing industry is rapidly growing into expensive assets, such as industrial machinery, automobiles, computer hardware, etc. The leasing industry comprises of thirty-three leasing companies and eight leasing Modaraba companies, with a business of 36 billion. According to (Ahmed et al., 2013) in the leasing sector in total other than public, immovable Assets outflows were estimated only $8 \%$ in Pakistan which is so little if we look at the other countries which use $40 \%$ of lease sector. Lease financing plays a vital role in meeting the financial requirements of firms as well as economic growth and progress of the financial system of a country. There are various methods to measure the performance of a firm like according to Tobin-Q we can measure performance through Return on Asset (ROA) and Return on equity (Al-Matari et al., 2014); providing performance measures by profit margin, earning per share and dividend yield, etc. An element which affects firm performance the most is corporate governance. If proper corporate governance functions are established, it will attract investors as well as maximize company funds and the final result will increase firm performance. Effective corporate governance will protect from financial challenges and will help in achieving remarkable growth so corporate governance ca be considered a key element for firm performance.

\subsection{Why lease financing is important for a firm?}

There are many reasons for which lease financing have been considered important for firms are given below:

- Leased assets are easy to get and use as compared to arranging debt and then purchase an asset.

- Periodic payments of a lease are operating expense and it is a tax detectable expense.

- If you sign a contract directly with the owner, you can display the leased asset in a footnote to the balance sheet.

- It is a more flexible way of financing you can adjust with your financing needs (Kumar and Lease, 2011).

\subsection{Purpose of the Study}

The sole purpose of the study is empirically determining the effect of financing through the lease on the performance of firms in oil and gas industry of Pakistan for the period of study 2013 to 2017.

\subsection{Significance of the Study}

The current study is important for the policy makers, management, potential investors of oil and gas companies in Pakistan, as well as lease financers in order make an important decision for the enhancement of their companies' financial performance. They would be able to 
analyze whether the financing of the lease has an important role in enhancing their firm's performance, if yes then at what direction they should expect? It will enhance the understanding of financial lease impact on their company's performance as well as will open the doors for future researchers in this domain.

\section{Literature Review}

Bello et al. (2016) studied the use of lease funding on the financial performance during (20052014) which is measured by R.O.A of Nigerian oil and gas sector. "Through Robust OLS analysis identify the effect of lease funding on return on assets". They used financial performance as the dependent variable and lease financing as an independent variable. Their findings show the substantial influence of financing through the lease on ROA of O\&G companies in Nigeria. Munene (2014) considered the financing of lease impact on monetary performance for listed firms in the stock exchange of Nairobi. The author's research is made up of 60 listed companies, but only 30 companies and secondary data collected from 2009 to 2013. The researchers used financial leasing, liquidity, enterprise size and leverage as independent variables, while using financial performance as a relevant variable. The author used regression analysis to find that financial leasing and finance performance have a negative effect on company performance, but the short term (ability to repay short-term creditors) and long-term debt paying abilities have a positive influence on the financial performance of enterprises. Akinbola and Otoki (2012) studied the impact of lease financing options on the ability to earn a profit of SMEs firms in Nigeria. Questionnaire Survey method was used, based on multi-stage random sampling. 300 of the respondents were small and medium-sized business managers in Lagos, Nigeria. They used frequency, simple percentages to analyze data. The variance and correlation are analyzed. They found that leasing options had a positive influence on the profitability of SMEs. Salam (2013) concluded the financial performances of SMEs is substantially impacted by lease financing. Financial performance was measured in terms of net asset/return on small and medium enterprises. The authors used a multi-stage random sampling questionnaire consisting of 53 small and mediumsized enterprises. The researcher used independent and dependent variables, i.e. use of lease and financial performance, respectively. Studies have found that leasing financing and corporate performance positively affect each other. By using the regression analysis and correlation analyses, it is found that monetary performance of Bangladeshi SMEs is immensely affected by the decision of leasing financing. Hassan et al. (2012) studied the "economic movements of Pakistani leasing companies over the past period". The authors used data for research during 2001-2010. They found Pakistan's financial trends by measuring sales, pre-tax profits, capital payments, equity and total assets. The variance analysis method was used to compare and the multivariate linear regression method was adopted. The researchers used financial trends as dependent variables and leasing finance as independent variables. Their fines were at their highest point in 2008, showing a positive attitude towards the leasing industry, with the average number of assets exceeding the rupee, 6 billion in the year 2008. Few years later, sales and total assets gradually declined, political and economic uncertainty was the reasons for lack of investment by an investor in Pakistan.

Alam et al. (2011) studied the leasing industry in Pakistan during the period of 2006-2009. They found that companies which used lease classified differently on the basis of financial leasing than the ones based on R.O.E and R.O.A. They used the right of abode, net assets, net worth and total asset in the financing lease. They used the lease ratio as independent variables and 
financial performance as related variables. They compared the financial ratios of the leasing company. Chimaleni et al. (2015) studied the relationship between the financing sources and the financial performance of SMEs in Lurambi countries. The population included $450 \mathrm{SMEs}$, out of which 88 small and medium-sized enterprises were taken as samples. The study found that corporate performance was a major impact of funding. They used correlation and multivariate regression to test their proposed hypotheses.

\subsection{Hypotheses}

The following three hypotheses have been developed after reviewing the relevant literature: Hypothesis 1

$H_{0}$ : There is a significant relationship between lease financing and firm performance.

$H_{1}$ : There is an insignificant relationship between lease financing and firm performance Hypothesis 2

$H_{0}$ : Size of the firm has an insignificant effect on firm performance.

$H_{1}$ : Size of the firm has a significant effect on firm performance.

Hypothesis 3

$H_{0}$ : Capital structure has insignificance effect on firm performance.

$H_{1}$ : Capital structure has significance effect on firm performance.

\subsubsection{Model}

$$
\mathrm{ROA}=\beta 0+\beta 1(L F)+\beta 2(F S)+\beta 3(C S)+\varepsilon
$$

Whereas;

$\mathrm{LF}=$ Lease Financing

FS = Firm Size

$\mathrm{CS}=$ Capital Structure

\section{Research Methodology}

\subsection{Data and Sample}

The sample consists of nine oil and gas companies. The data were collected from the financial statement of relevant companies, which measured firm performance during the period 2013 $-2017$.

\subsection{Variables}

\subsection{Independent Variable}

Independent variable for this study is leased financing. Lease financing has been operationalized by lease financed asset to total asset ratio. 


\subsubsection{Dependent Variable}

Firm performance was taken as a dependent variable for this study. Firm performance was measured by R.O.A and R.O.A defined by the ratio of profit after tax to assets.

\section{Return on assets $=$ Net profit/total assets}

\subsubsection{Control Variable}

For this research, firm size and debt to asset ratio has been used as control variables. Firm size is defined by a log of sales and debt to asset ratio has been defined by a ratio of debt to assets.

$$
\text { Firm Size }=\log (\text { sales })
$$

Debt to Asset Ratio $=$ Total debt/total assets

\section{Results \& Discussion}

This section contains results of the study. For the purpose of data analysis, descriptive statistics, correlation matrix, and regression analysis were applied in different sections.

\subsection{Descriptive Statistics}

For the proper summarization of the variables of the study, the descriptive statistics were applied to find out the different measures like mean, standard deviation, median, standard error of the mean, sample variance, Kurtosis, skewness, range, minimum, maximum, sum, and count. For this purpose, the following table was generated to analyze the current study:

Table 1 indicates the descriptive statistics for the current study. It shows that the average contribution of ROA in the current study is 8.06 , lease financing as 1.38 , firm size as 10.95 and finally debt ratio as 62.85 which indicates that on average debt ratio is contributing more in the current study. The median value is also high in case of debt ratio as 61.16 while the median values for other variables are; $\mathrm{ROA}=5.52$, lease financing $=0.42$ and firm size $=11.18$ in the current study.

\subsection{Correlation Matrix}

For the purpose of analyzing the association and direction of the relationship between the variables of the study, the Pearson correlation was computed and the output is given below in Table 2:

Table 2 indicates the association between the variables of the study like ROA, lease financing, firm size and Debt ratio. The table 2 indicates that there is a moderate negative association between lease financing and ROA having a value of the coefficient of Pearson correlation as 0.40 between the variables. The results also indicate a weak positive association between firm size and ROA. The value of the coefficient between the variable is 0.05 according to Pearson correlation. The table also indicates a strong and negative association between debt ratio and ROA. The value of the coefficient is -0.83 between the variables. There is a weak positive association between Firm size and Lease financing with the coefficient's value as 0.11 between 
Table 4.1: Descriptive Statistics for the Variables

\begin{tabular}{lcccc}
\hline & ROA & Lease Financing & Firm Size & Debt Ratio \\
\hline Mean & 8.06 & 1.38 & 10.95 & 62.85 \\
SE & 1.30 & 0.29 & 0.12 & 3.21 \\
Median & 5.52 & 0.42 & 11.18 & 61.16 \\
SD & 8.20 & 1.86 & 0.79 & 20.30 \\
SV & 67.19 & 3.47 & 0.62 & 412.28 \\
Kurtosis & 0.42 & 3.21 & 0.22 & -0.43 \\
Skewness & 1.05 & 1.91 & -0.97 & -0.61 \\
Range & 33.28 & 7.79 & 3.20 & 69.85 \\
Min & -4.64 & 0.04 & 8.88 & 20.26 \\
Max & 28.64 & 7.84 & 12.07 & 90.12 \\
Sum & 322.40 & 55.38 & 437.88 & 2514.13 \\
Count & 40.00 & 40.00 & 40.00 & 40.00 \\
\hline
\end{tabular}

Table 4.2: Correlation Matrix for the Variables

\begin{tabular}{lcccc}
\hline & ROA & Lease Fin & Firm Size & Debt Ratio \\
\hline ROA & 1 & & & \\
Lease Fin & -0.40 & 1 & & \\
Firm Size & 0.05 & 0.11 & 1 & \\
Debt Ratio & -0.83 & 0.44 & 0.23 & 1 \\
\hline
\end{tabular}

the variables. There is a moderate positive association between debt ratio and lease financing having the value of coefficient as 0.44 between the variables. Finally, table 2 also indicates a weak positive association between debt ratio and firm size with the value of coefficient as 0.23 between the variables.

\subsection{Regression Analysis}

For the purpose of analyzing the linearity and strength of the relationship between dependent and independent variables, the regression analysis was being conducted and shown the output in the form of Model summary in Table 3, ANOVA in Table 4 and results of the coefficient in Table 5 as follow:

Table 3 indicates the summarized results of the model applied with an overall statistical significance of the model. The table shows $\mathrm{R}=.869$ which indicates the overall correlation between the variables of the study. $\mathrm{R}$-square $=.755$ indicates that approximately $76 \%$ variation in the dependent variables which is ROA (firm performance) is explained by the variation of indepen- 
Table 4.3: Model Summary

\begin{tabular}{lcccc}
\hline Model & $\mathbf{R}$ & $\mathbf{R ~ S q}$ & Adj R Sq & SE est \\
\hline 1 & $.869^{a}$ & .755 & .734 & 4.2598 \\
\hline a. Predictors: (Constant), LF, Firm Size, Debt & Ratio \\
b. Dependent & Variable: & ROA
\end{tabular}

dent variables like Lease financing, Firm size, and debt ratio. The remaining $24 \%$ variation in the firm performance is due to the unobserved factors which were not included in the model. The adjusted R-square $=.734$ indicates that with the more independent variables in the model, the variation in the firm performance of the Oil and Gas sector can adjust to $73 \%$ approximately. The value for the standard error of estimate $=4.26$ approximately indicates the accuracy of estimates according to Table 3.

Table 4.4: ANOVA $^{a}$

\begin{tabular}{ccccccc}
\hline \multicolumn{2}{l}{ Model } & SS & DF & MS & F & Sig. \\
\hline 1 & Reg & 2007.78 & 3 & 669.24 & 36.88 & $.000^{b}$ \\
& Resid & 653.26 & 36 & 18.15 & & \\
& Total & 2660.98 & 39 & & & \\
\hline
\end{tabular}

a. Dependent Variable: ROA

b. Predictors: (Constant), Lease Financing, Firm Size, Debt Ratio

Table 4 indicates the results of ANOVA which is analysis of variation of the study. It shows that variation between the variables due to the regression model is 2007.78 and due to residual, the variation is 653.26 , the total sum of square indicates the total variation in the study, which is 2660.8 as Sum of squares total. The Statistical fitness of the model is indicated by $F(3,36.881)$ $=0.000$ which indicates that there is a linear relationship between dependent and independent variables of the study.

Table 4.5: Coefficients

\begin{tabular}{lccccc}
\hline Model & \multicolumn{6}{c}{ Unstand Coeff } & Stand Coeff & $\mathbf{t}$ & Sig. \\
\hline & Beta & Std. E & Beta & & \\
\hline 1 (Cons) & -5.87 & 10.50 & & -.560 & .579 \\
Firm Size & 3.44 & 1.019 & .297 & 3.382 & .002 \\
Debt Ratio & -.370 & .040 & -.906 & -9.278 & .000 \\
Lease Fin & -.078 & .411 & -.018 & -.190 & .850 \\
\hline
\end{tabular}

Table 5 indicates the coefficient results of the study. It shows that Firm size has highly significant and positive relationship with firm performance in the Oil and Gas industry of Pakistan 
while the debt ratio has the negative and significant relationship with firm performance and the lease financing has the negative but insignificant relationship with firm performance. The coefficient value for firm size is .297 and the p-value is .002 showing that 1 unit increase in firm size will increase the firm performance by .297 which rejects the null hypothesis and accepts the alternative. The value of coefficient between debt ratio and firm size is -.906 with p-value as .000 as the highest significance value of the study shows that 1 unit increase in debt ratio will decrease the firm performance by .906 negatively. This rejects the null hypothesis and accepted the alternative. The value of the coefficient for the relationship between lease financing and firm performance is -.018 with the p-value as .850 showing a one-unit increase in lease financing, which may decrease the firm performance in Oil and Gas sector of Pakistan by .018. This result rejects the null hypothesis which shows a significant relationship between both variables and accepts the alternative hypothesis.

\section{Conclusion}

\subsection{Summarized Findings}

The results indicate that financial performance of firm is being negatively influenced by lease financing but question is why? Normally we see that lease financing has a positive impact on firm performance but the current study shows negative influence which means its effect changes from industry to industry. It does not mean that lease financing has a positive impact on every kind of industry like here in oil and gas industry of Pakistan. The reason might be that oil and gas industry's machinery requires a huge amount of capital and its impact will also be on lessor requirement for lease payment so they will demand more annual lease payment. So, in this firm expense will rise and its result will decrease its profitability. Munene (2014) also studied "the lease financing effect on a firm's financial performance listed in the stock exchange of Nairobi and their result shows that lease and firm size both have a negative impact on financial performance of the firm. It has also been concluded that firm financial performance is positively influenced by firm size, same as various authors already concluded that "firm performance is positively influenced by firm size". A study by Olawale et al. (2017) posited that there is a positive relationship between firm size and firm performance. Finally, the firm performance is positively and significantly influenced by capital structure of firm as concluded by Iavorskyi (2013), i.e. Financial leverage has a positive and significant impact on firm performance by disciplining managers, tax shield and signaling effect.

\subsection{Practical Implications}

The policy makers and management in the oil and gas sector of Pakistan should consider the possible effect of lease financing being negative, as well as debt ratio, , being significant as well as negative, while the effect of firm's size is positive and significant which will enhance the firm's performance in this industry.

\section{References}

Ahmed, R., Siddiqui, K., and Immamuddin, M. D. (2013). Leasing industry in pakistan: Problems
\& prospects. Asian Journal of Research in Banking and Finance, 3(7):24-31.

Akinbola, O. and Otoki, B. (2012). Effects of lease options as a source of finance on profitability 
performance of small and medium enterprises (smes) in lagos state, nigeria. International Journal of Economic Development Research and Investment Vol. 3 No3, Dec 2012.

Al-Matari, E. M., Al-Swidi, A. K., and Fadzil, F. H. B. (2014). The measurements of firm performance's dimensions. Asian Journal of Finance $\mathcal{E}$ Accounting, 6(1):24.

Alam, H. M., Raza, A., Farhan, M., and Akram, M. (2011). Leasing industry in pakistan: a comparison of financial performance of leasing companies. International Journal of Business and Social Science, 2(10).

Bello, U., Ahmad, H. S., and Aliyu, A. A. (2016). The impact of lease financing on financial performance of nigerian oil and gas industry. Research Journal of Finance and Accounting, 7(4):28-34.

Chimaleni, J., Muganda, M., and Musiega, D. (2015). Relationship between sources of business financing and financial performance of small and medium enterprises in lurambi sub-county. International Journal of Business and Management Invention, 4:35-45.

Hameed, A., Ramzan, M., Zubair, H. M. K., et al. (2014). Impact of compensation on employee performance (empirical evidence from banking sector of pakistan). International Journal of Business and Social Science, 5(2).
Hassan, Y., Kashif-ud din, K. U., Ahmed, K., Eijaz, F., Younis, M., Yaseen, A., Naseer, A., Buttar, H., and Mateen, A. (2012). The comprehensive study of the capital structure of textile composite in pakistan over the decade. Interdisciplinary Journal of Contemporary Research in Business, 3(9):311-324.

Iavorskyi, M. (2013). The impact of capital structure on firm performance: Evidence from ukraine. Kyiv School of Economics, 36.

Kumar, A. and Lease, M. (2011). Modeling annotator accuracies for supervised learning. In Proceedings of the Workshop on Crowdsourcing for Search and Data Mining (CSDM) at the Fourth ACM International Conference on Web Search and Data Mining (WSDM), pages 19-22.

Munene, W. W. (2014). The effect of lease financing on the financial performance of companies listed at the nairobi securities exchange. Unpublished M. Sc. thesis, Department of finance and accounting, School of Business, University of Nairobi.

Olawale, L. S., Ilo, B. M., and Lawal, F. K. (2017). The effect of firm size on performance of firms in nigeria. Aestimatio: The IEB International Journal of Finance, (15):68-87.

Salam, A. (2013). Effects of lease finance on performance of smes in bangladesh. International Journal of Science and Research, 2:12. 